Article

\title{
Immobilization of Potentially Toxic Elements (PTE) by Mineral-Based Amendments: Remediation of Contaminated Soils in Post-Industrial Sites
}

\author{
Maja Radziemska ${ }^{1, *(1)}$, Agnieszka Bęś ${ }^{2}{ }^{(0)}$, Zygmunt M. Gusiatin ${ }^{3}{ }^{(0)}$, Grzegorz Majewski $^{1}$, \\ Zbigniew Mazur ${ }^{2}$, Ayla Bilgin ${ }^{4}$ (D) , Iwona Jaskulska ${ }^{5}$ and Martin Brtnický ${ }^{6,7}$ (D) \\ 1 Institute of Environmental Engineering, Warsaw University of Life Sciences, Nowoursynowska 159, \\ 02-776 Warsaw, Poland; grzegorz_majewski@sggw.pl \\ 2 Faculty of Environmental Management and Agriculture, University of Warmia and Mazury in Olsztyn, Pl. \\ Łódzki 4, 10-727 Olsztyn, Poland; agnieszka.bes@uwm.edu.pl (A.B.); zbigniew.mazur@uwm.edu.pl (Z.M.) \\ 3 Faculty of Geoengineering, University of Warmia and Mazury in Olsztyn, Słoneczna St. 45G, \\ 10719 Olsztyn, Poland; mariusz.gusiatin@uwm.edu.pl \\ 4 Faculty of Engineering, Artvin Coruh University, Seyitler Campus, 08000 Artvin, Turkey; \\ ayla.bilgin@artvin.edu.tr \\ 5 Faculty of Agriculture and Biotechnology, UTP University of Science and Technology, Bernardyńska 6/8, \\ 85-029 Bydgoszcz, Poland; jaskulska@utp.edu.pl \\ 6 Faculty of AgriSciences, Mendel University in Brno, Department of Agrochemistry, Soil Science, \\ Microbiology and Plant Nutrition, 61300 Brno, Czech Republic; martin.brtnicky@seznam.cz \\ 7 Institute of Chemistry and Technology of Environmental Protection, Faculty of Chemistry, Brno University \\ of Technology, 61200 Brno, Czech Republic \\ * Correspondence: maja_radziemska@sggw.pl; Tel.: +48-2259-353-70
}

Received: 14 December 2019; Accepted: 20 January 2020; Published: 21 January 2020

\begin{abstract}
In many post-industrial sites, the high contents and high mobility of different potentially toxic elements (PTEs) make the soils unsuitable for effective management and use. Therefore, immobilization of PTE seems to be the best remediation option for such areas. In the present study, soil samples were collected in post-industrial areas in Northeastern Poland. The analyzed soil was characterized by especially high contents of $\mathrm{Cd}\left(22 \mathrm{mg} \cdot \mathrm{kg}^{-1}\right), \mathrm{Pb}\left(13540 \mathrm{mg} \cdot \mathrm{kg}^{-1}\right)$, and Zn $\left(8433 \mathrm{mg} \cdot \mathrm{kg}^{-1}\right.$ ). Yellow lupine (Lupinus luteus L.) and two types of mineral-based amendments were used to determine their combined remediation effect on PTE immobilization. A greenhouse pot experiment was conducted to evaluate the influence of chalcedonite and halloysite on plant growth, chlorophyll $a$ fluorescence, the leaf greenness index (SPAD), PTE uptake, and the physicochemical properties and toxicity of soil. The application of chalcedonite resulted in the greatest increase in soil $\mathrm{pH}$, whereas halloysite contributed to the greatest reduction in the contents of $\mathrm{Ni}, \mathrm{Pb}, \mathrm{Zn}$, and $\mathrm{Cr}$ in soil, compared with the control treatment. The addition of halloysite significantly increased plant biomass. The application of mineral-based amendments increased the ratio of variable fluorescence to maximum chlorophyll fluorescence $(\mathrm{Fv} / \mathrm{Fm})$ in yellow lupine leaves. The leaf greenness index was highest in plants growing in soil amended with chalcedonite. The results of this study suggest that mineral-based amendments combined with yellow lupine could potentially be used for aided phytostabilization of multi-PTE contaminated soil in a post-industrial area.
\end{abstract}

Keywords: soil amendments; immobilization; halloysite; chalcedonite

\section{Introduction}

Rapid industrialization and population growth in the last century have led to adverse changes in the natural environment [1]. Soil, water, and air pollution can pose considerable threats for human 
health and distort the natural balance of ecosystem components [2]. Anthropogenic pressure disrupts biogeochemical cycles and increases the contents of PTE in the environment, which creates serious problems on the local and global scale [3]. Efforts are being made to restore degraded soils and decrease the content of contaminating substances below the established threshold values [4]. In many cases, soil quality standards cannot be met for technical or financial reasons; therefore, the main aim of restoration is to reduce contamination availability and its adverse environmental impact.

Phytoremediation poses a viable alternative to other restoration methods [5]. It can be used independently or in combination with conventional methods of soil and water remediation. Phytoremediation is effective in purifying not only small but also large degraded areas [6]. Phytostabilization has attracted considerable interest in recent years because it is a technique which relies on plants to immobilize pollutants in soil and reduce their bioavailability in the environment [7]. Contaminants like PTE are immobilized when they are absorbed and accumulated in plant roots, adsorbed on root surfaces, and precipitated in the rhizosphere [8]. The chemical compounds secreted by plant roots into the rhizosphere decrease the bioavailability of PTE. This remediation method protects soil from further degradation, including erosion, and the immobilized compounds are less likely to migrate to other links in the food chain [9]. Phytostabilization effectively diminishes ecological risk in soil containing both organic and inorganic pollutants. Another advantage is the fact that in areas where the phytostabilization is applied, the above-ground plant parts have a low content of PTE; therefore, they can be effectively used to generate energy in all biomass conversion processes (combustion, co-combustion, fermentation).

Compounds that deactivate and immobilize PTE ions in soil can be additionally used in phytostabilization. Mineral-based amendments such as phosphogypsum [10], calcium carbonate, bentonite [11], sulfo-calcic fly ash [12], mixtures of diammonium phosphate and hydroxyapatite [13], calcium carbonate [14], hydrated lime [15], diatomite, and dolomite [16] have been described in the literature. The effectiveness of phytostabilization is determined by the type and quantity of soil amendments. Therefore, effective and inexpensive compounds of natural origin are being researched, including mineral-based amendments such as chalcedonite and halloysite. Chalcedonite is a siliceous rock, and its chemical and phase composition make it highly suitable for a wide range of applications [17]. Chalcedonite has a homogenous chemical composition with an estimated $94 \%$ content of silicon dioxide $\left(\mathrm{SiO}_{2}\right)$. Chalcedonite rock is composed mainly of chalcedony with small amounts of quartz, opal, iron hydroxides, pyrite, manganese compounds, and clay minerals. Chalcedonite is a mesoporous material with a relatively uniform pore structure and a total pore volume of $0.03-0.04 \mathrm{~cm}^{3} \cdot \mathrm{g}^{-1}$ [18]. Halloysite is composed of nanotubes, and it is characterized by high porosity and specific surface area, high cation exchange capacity, and ease of chemical and mechanical processing. Although it contains trace amounts of contaminants, it is highly stable across a wide $\mathrm{pH}$ range [19]. The chemical composition of halloysite is highly similar to kaolin. The main structural component in this group of minerals is the 1:1 kaolinite group of clay minerals with the crystal-chemical formula $\mathrm{Al}_{4} \mathrm{Si}_{4} \mathrm{O}_{10}(\mathrm{OH})_{8}[20]$. Halloysite has many applications in engineering and environmental protection, and it is widely used as a mineral adsorbent for removing toxic substances and PTE from water and wastewater [21,22]. Halloysite has not commonly been tested because, although a large amount of it is available, there are only three halloysite mines in the world. Halloysite is characterized by a large specific surface area (approximately 65,000-400,000 $\mathrm{m}^{2} \cdot \mathrm{kg}^{-1}$ ) and considerable porosity (60-70\%) [23]. Despite the favorable properties of chalcedonite and halloysite, there has been little research into their application in assisted phytostabilization of chemically degraded soils.

In view of the above, the aim of this study was to evaluate the effect of mineral-based amendments on assisted phytostabilization of soil heavily contaminated with mixed PTE. The phytotoxic and phytochemical properties of the soil and the chemical composition of the plants were analyzed, and chlorophyll $a$ fluorescence and the leaf greenness index (SPAD) were determined. 


\section{Materials and Methods}

\subsection{Mineral-Based Amendments and Experimental Design}

Two mineral-based amendments, i.e., chalcedonite (limited liability company Chalcedon Poland, Inowłódz, Poland) and halloysite ("Dunino" strip mine, Intermark Company, Legnica, Poland), were mixed with soil in the amount of $3.0 \%(w / w)$. Soil without the amendments $(0.0 \%, w / w)$ was the control treatment. Soil samples were thoroughly mixed, and pots filled with soil with a moisture content at $60 \%$ of water holding capacity were left in a dark room for over 3 weeks to equilibrate the soil mixture. Each treatment was replicated three times. Scanning electron microscope (SEM) images of mineral-based amendments are presented in Figure 1. The oxides content in soil amendments was measured using X-ray diffraction (XRD) analysis (Philips X-ray Diffractometer with X'Celerator Detector), while the specific surface area was measured with a Micromeritics ASAP 2020 BET N2 (Norcross, GA, USA). Table 1 presents selected properties of the mineral-based amendments used in the experiment.

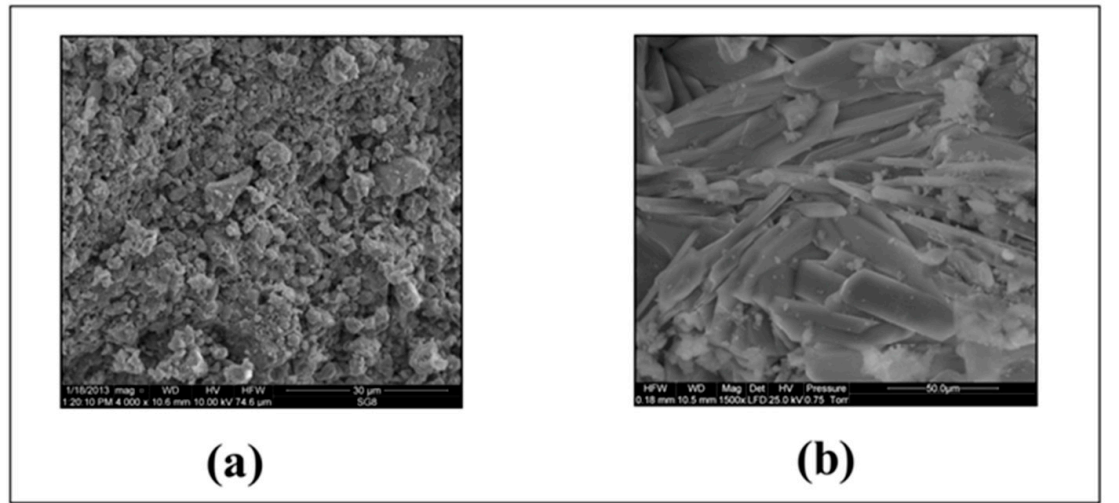

Figure 1. Scanning electron microscope (SEM) images of chalcedonite (a) and halloysite (b).

Table 1. Properties of mineral-based amendments.

\begin{tabular}{|c|c|c|c|}
\hline Parameter & $\begin{array}{l}\text { Chemical Composition } \\
\text { in Oxide (wt. \%) }\end{array}$ & $\begin{array}{l}\text { Specific Surface } \\
\text { Area }\left(\mathrm{m}^{2} \cdot \mathrm{g}^{-1}\right)\end{array}$ & $\mathrm{pH}$ \\
\hline Chalcedonite & $\begin{array}{c}\mathrm{SiO}_{2}-89.06 \pm 0.46 ; \mathrm{Al}_{2} \mathrm{O}_{5}-9.33 \pm \\
0.14 ; \mathrm{K}_{2} \mathrm{O}-1.21 \pm 0.08 \\
\mathrm{MgO}-0.40 \pm 0.011\end{array}$ & 7.44 & 7.12 \\
\hline Halloysite & $\begin{array}{c}\mathrm{SiO}_{2}-39.6, \mathrm{Al}_{2} \mathrm{O}_{3}-37.0 \\
\mathrm{Fe}_{2} \mathrm{O}_{3}-16.1, \mathrm{TiO}_{2}-2.30 \\
\mathrm{CaO}-0.66, \mathrm{MgO}-0.13 \\
\mathrm{Na}_{2} \mathrm{O}-0.04, \mathrm{~K}_{2}-0.05 ; \mathrm{P}_{2} \mathrm{O}_{5}-0.52\end{array}$ & 75.0 & 7.66 \\
\hline
\end{tabular}

The experiment was conducted in a naturally ventilated greenhouse. The tested plant species was yellow lupine (L. luteus) cv. Perkoz which was planted in $5.0 \mathrm{~kg}$ polyethylene pots. The plants were watered every other day with deionized water to maintain $60 \%$ of the maximum water holding capacity of the soil. At the end of the experiment (approximately 54 days after sowing), lupine plants were harvested, weighed, and separated into the roots and above-ground parts.

\subsection{Soil from Post-Industrial Areas Used in the Experiment}

In this study, samples of soil heavily co-contaminated with $\mathrm{Cd}, \mathrm{Pb}$, and $\mathrm{Zn}$ were collected from a depth of 0-20 cm in post-industrial areas in Northeastern Poland (53 47'3.48 ${ }^{\prime \prime} \mathrm{N}$; $20^{\circ} 30^{\prime} 52.56^{\prime \prime} \mathrm{E}$ ) using the method described by Pan et al. [24]. The study area mainly stores ferrous and non-ferrous metal waste since 1946. About $150 \mathrm{~kg}$ of soil were sampled from several dozen points located within 
an area of $1000 \mathrm{~m}^{2}$. At each sampling point, 5 soil samples were collected using a soil auger and mixed to achieve a composite soil sample representing a given sampling point. Before the pot experiment, the samples were air-dried and passed through a $2 \mathrm{~mm}$ nylon sieve. The soil, classified as loamy fine sand, was composed of $76 \%$ sand, $23 \%$ silt, and $1 \%$ clay fractions. The selected physicochemical properties of the soil are presented in Table 1.

\subsection{Soil Analysis}

Before the experiment, soil samples were assayed for $\mathrm{pH}$ and electrical capacity (EC) in distilled water extracts $(1: 2.5 w / v)$ using a pH-meter (HI 221) and cation exchange capacity (CEC), calculated as the sum of hydrolytic acidity (in $1 \mathrm{M} \mathrm{Ca}\left(\mathrm{CH}_{3} \mathrm{COO}\right)_{2}$ ) and exchangeable bases (in $0.1 \mathrm{M} \mathrm{HCl}$ ). Soil organic matter was determined by combustion at $550{ }^{\circ} \mathrm{C}$. The total content of PTE $(\mathrm{Cd}, \mathrm{Cr}, \mathrm{Cu}, \mathrm{Ni}$, $\mathrm{Pb}, \mathrm{Zn}$ ) was determined with a flame atomic absorption spectrometer (FAAS) (Varian AA28OFS, Mulgrave, Australia) using the U.S. Environmental Protection Agency Method 3050B after soil digestion in a mixture of concentrated $\mathrm{HCl}, \mathrm{HNO}_{3}$, and $\mathrm{H}_{2} \mathrm{O}_{2}$ in a microwave oven (MARSXpress, CEM Corporation, Matthews, NC, USA) using a single-stage program (ramp to temperature for $30 \mathrm{~min}$, hold samples at $170{ }^{\circ} \mathrm{C}$ for $45 \mathrm{~min}$ ). The extracts after mineralization were filtered through Whatman filters into $50 \mathrm{~mL}$ glass flasks. The accuracy of PTE analysis by FAAS was validated by analyzing the reference material, CRM $142 \mathrm{R}$.

\subsection{Plant Material Analysis}

At the end of the experiment, the harvested L. luteus plants were divided into shoot and root parts. The plant material was carefully washed with ultrapure water to remove soil particles, and then air-dried at room temperature. Before chemical analyses, the plants were powdered using an analytical mill (Retsch type ZM300, Hann, Germany) and kept at ambient temperature. The contents of PTE in the above-ground parts and roots of plants were determined by mineralizing them in a microwave oven with concentrated $\mathrm{HNO}_{3}$.

Chlorophyll $a$ fluorescence in the plants was measured during the growing season with the Handy-PEA portable chlorophyll fluorimeter (Hansatech Instruments Ltd., Pentney, UK). Measurements were conducted on two randomly selected, fully developed leaves, and the results were averaged (five plants per pot, two measurements per plant). The maximum quantum efficiency of PSII (Fv/Fm ratio; Fv is the variable fluorescence; Fm is the maximum fluorescence), as an indicator of plant adaptation to dark, was determined on lupine leaves three times during the experiment. Before the measurements, leaves were covered with clips for $30 \mathrm{~min}$ for dark adaptation. Fluorescence emission was induced on $4 \mathrm{~mm}^{2}$ of leaf surface area with a light intensity of $3000 \mu \mathrm{mol} \mathrm{m}^{-2} \mathrm{~s}^{-1}$. Maximum fluorescence (MF) was measured for $100 \mathrm{~ms}$. Fluorescence kinetics were analyzed in the Pocket PEA Plus V1.10 program (Hansatech Instruments Ltd., Pentney, UK). The leaf greenness index (SPAD) was determined on ten leaves in each plant with the SPAD 502 chlorophyll meter (Konica Minolta, Tokyo, Japan). The leaf greenness index was expressed in dimensionless SPAD units. All measurements were conducted in triplicate.

\subsection{Ecotoxicological Analysis}

The phytotoxicity of contaminated soils was determined with the Phytotoxkit seed germination biotest and an early growth microbiotest (Microbiotests Inc., Ghent, Belgium). Phytotoxicity analyses were also carried out in soils with mineral-based amendments (halloysite and chalcedonite). The analyses were conducted in triplicate, and Phytotoxkit soil was the control treatment. Phytotoxicity tests were performed with the use of sorghum (Sorghum saccharatum L.) seeds. Observations were conducted for seven days, and digital images were acquired every day. Root length was measured by digital image analysis in the Image Tool 3.0 program (UTHSCSA, San Antonio, TX, USA). The results 
were used to calculate the percentage inhibition of seed germination and root growth with the use of the following formula:

$$
\mathrm{I}=((\mathrm{A}-\mathrm{B})) / \mathrm{A} \times 100,
$$

where: I-inhibition (\%), A — seed germination or the length of roots in control soil, B-seed germination or the length of roots in the tested soils (with and without mineral-based amendments).

\subsection{Statistical Analysis}

The results of the experiment were processed statistically in the Statistica 13.3 program (San Diego, CA, USA). The normality of data distribution in every independent group was determined in the Shapiro-Wilk test, and the residuals were additionally checked for normality. The homogeneity of variance was verified by Levene's test. The significance of differences between means was determined by one-way ANOVA (F-test). Significant differences $(p<0.05)$ between the mean values of different treatments were evaluated and compared in Tukey's range test. The results were also subjected to Principal Component Analysis (PCA) in the XLStat program (Addinsoft, Paris, France).

\section{Results}

\subsection{Soil Parameters}

The analyzed soils had a $\mathrm{pH}$ of $7.54 \pm 0.4$, pointing to alkaline conditions. The mean contents of PTE are presented in Table 2. Soil contamination was evaluated based on the classification set forth in the Regulation of the Polish Ministry of the Environment [25]. The contents of $\mathrm{Cd}, \mathrm{Pb}$, and $\mathrm{Zn}$ in degraded soils from post-industrial areas exceeded the thresholds values given in the above classification. The contents of the remaining PTE were within the safe range.

Table 2. Selected properties of the analyzed soil.

\begin{tabular}{|c|c|c|c|}
\hline Parameter & Unit & Value & Acceptable Values ${ }^{a}$ \\
\hline $\mathrm{pH}$ & - & $7.54 \pm 0.4$ & - \\
\hline Electrical conductivity & $\mathrm{mS} \cdot \mathrm{cm}^{-1}$ & $0.84 \pm 0.3$ & - \\
\hline Organic matter & $\% \cdot d . m$. & $11 \pm 2.1$ & - \\
\hline Cation Exchange Capacity & $\mathrm{C} \mathrm{mol}(+) \cdot \mathrm{kg}^{-1}$ & $51.9 \pm 2.7$ & - \\
\hline Cadmium $(\mathrm{Cd})$ & $\mathrm{mg} \cdot \mathrm{kg}^{-1}$ & $22 \pm 2.5$ & 15 \\
\hline Copper $(\mathrm{Cu})$ & $\mathrm{mg} \cdot \mathrm{kg}^{-1}$ & $496 \pm 144.4$ & 600 \\
\hline Chromium (Cr) & $\mathrm{mg} \cdot \mathrm{kg}^{-1}$ & $352 \pm 61.1$ & 500 \\
\hline Nickel (Ni) & $\mathrm{mg} \cdot \mathrm{kg}^{-1}$ & $113 \pm 24.5$ & 300 \\
\hline Lead $(\mathrm{Pb})$ & $\mathrm{mg} \cdot \mathrm{kg}^{-1}$ & $13,540.0 \pm 669.6$ & 600 \\
\hline Zinc (Zn) & $\mathrm{mg} \cdot \mathrm{kg}^{-1}$ & $8430 \pm 1376.5$ & 1000 \\
\hline
\end{tabular}

${ }^{a}$ threshold values set forth by the Regulations of the Polish Ministry of the Environment [25]. The values in bold significantly exceed threshold contents.

\subsection{Soil Parameters after the Addition of Mineral-Based Amendments}

The $\mathrm{pH}$ of soil from post-industrial areas was affected by the type of mineral-based amendments (Figure 2). Chalcedonite induced the greatest increase in soil pH, from 8.14 in the control treatment to 8.25. The PTE content of phytostabilized soil is presented in Figure 3. The total contents of $\mathrm{Ni}, \mathrm{Pb}, \mathrm{Zn}$, and $\mathrm{Cr}$ were most effectively reduced by halloysite, relative to non-amended control soil. Chalcedonite decreased the total amounts of $\mathrm{Cu}$ and $\mathrm{Cd}$ in the analyzed soil. 


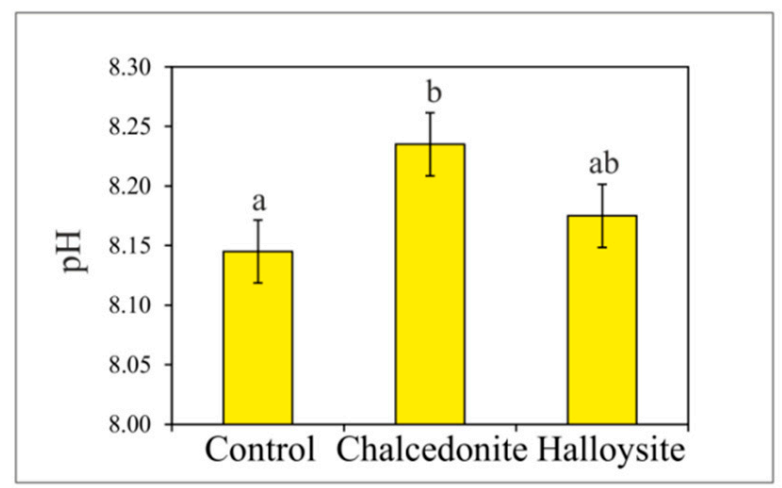

Figure 2. Soil $\mathrm{pH}$ after phytostabilization. Error bars \pm standard error $(n=3)$. Different letters denote significant differences between treatments.
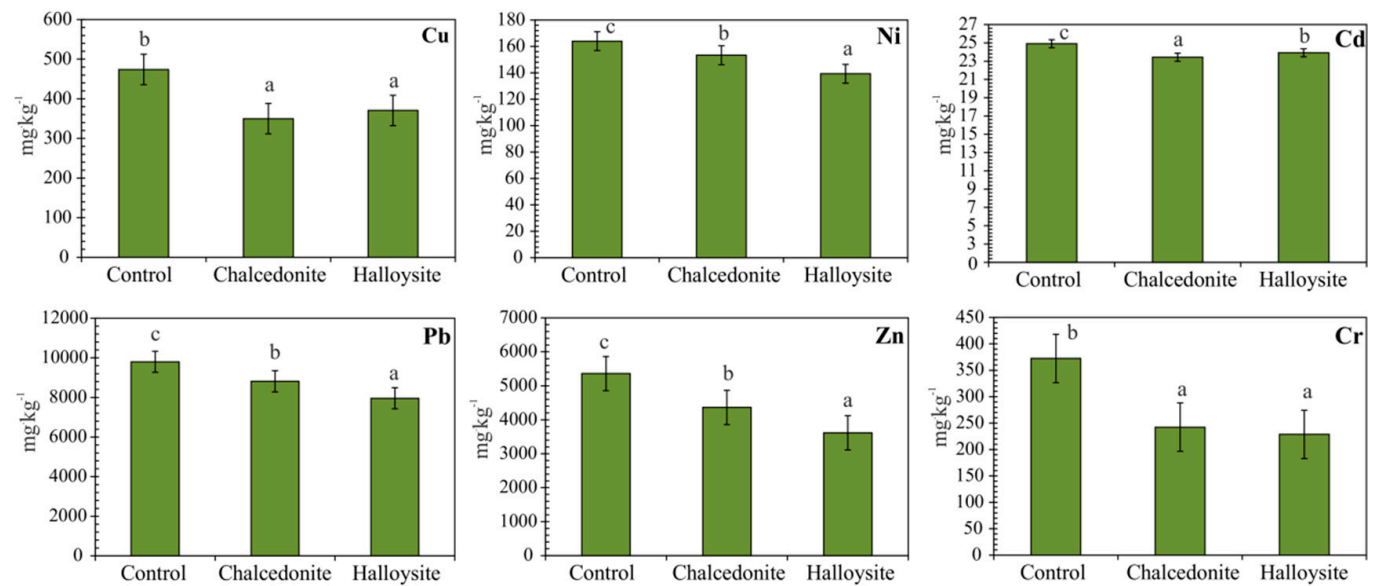

Figure 3. Total potentially toxic elements (PTE) contents in soil after the application of mineral-based amendments. Error bars \pm standard error $(n=3)$. Different letters denote significant differences between treatments.

\subsection{Plant Growth after the Addition of Mineral-Based Amendments}

The yield of the above-ground biomass of L. luteus is presented in Figure 4. The analyses of plant growth and development indicate that chalcedonite and halloysite increased the yield of the above-ground biomass of L. luteus. Halloysite contributed to the greatest increase in the yield of above-ground biomass relative to the control treatment.

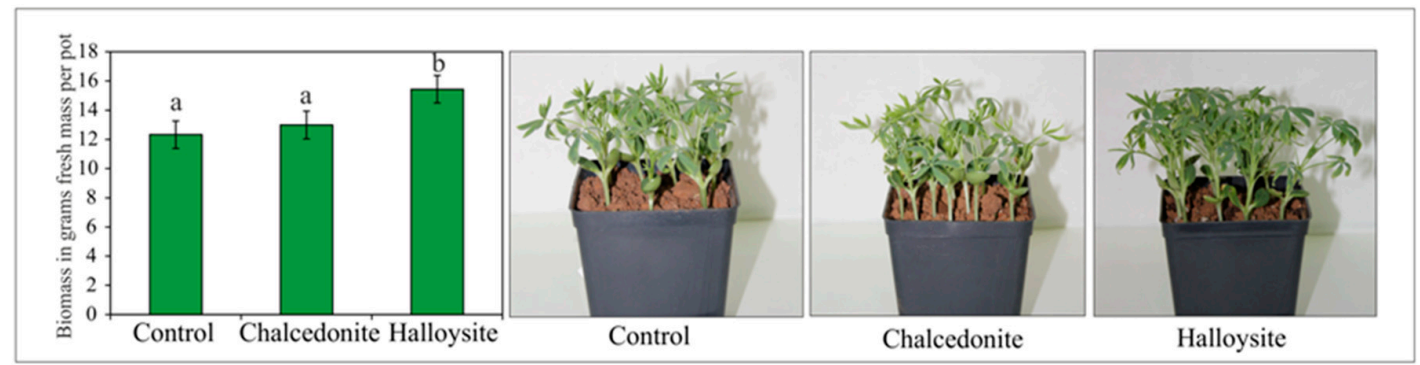

Figure 4. The effect of mineral-based amendments on the yield of above-ground biomass of L. luteus. Error bars \pm standard error $(n=3)$. Different letters denote significant differences between treatments.

\subsection{PTE Accumulation in L. luteus}

The effect of mineral-based amendments on PTE accumulation in the roots and above-ground biomass of L. luteus is presented in Figure 5. The analyzed PTE were accumulated mostly in lupine roots. 
In comparison with the non-amended control treatment, halloysite led to the greatest accumulation of $\mathrm{Ni}$ and $\mathrm{Cr}$, whereas chalcedonite resulted in the greatest accumulation of $\mathrm{Cd}$ in lupine roots.
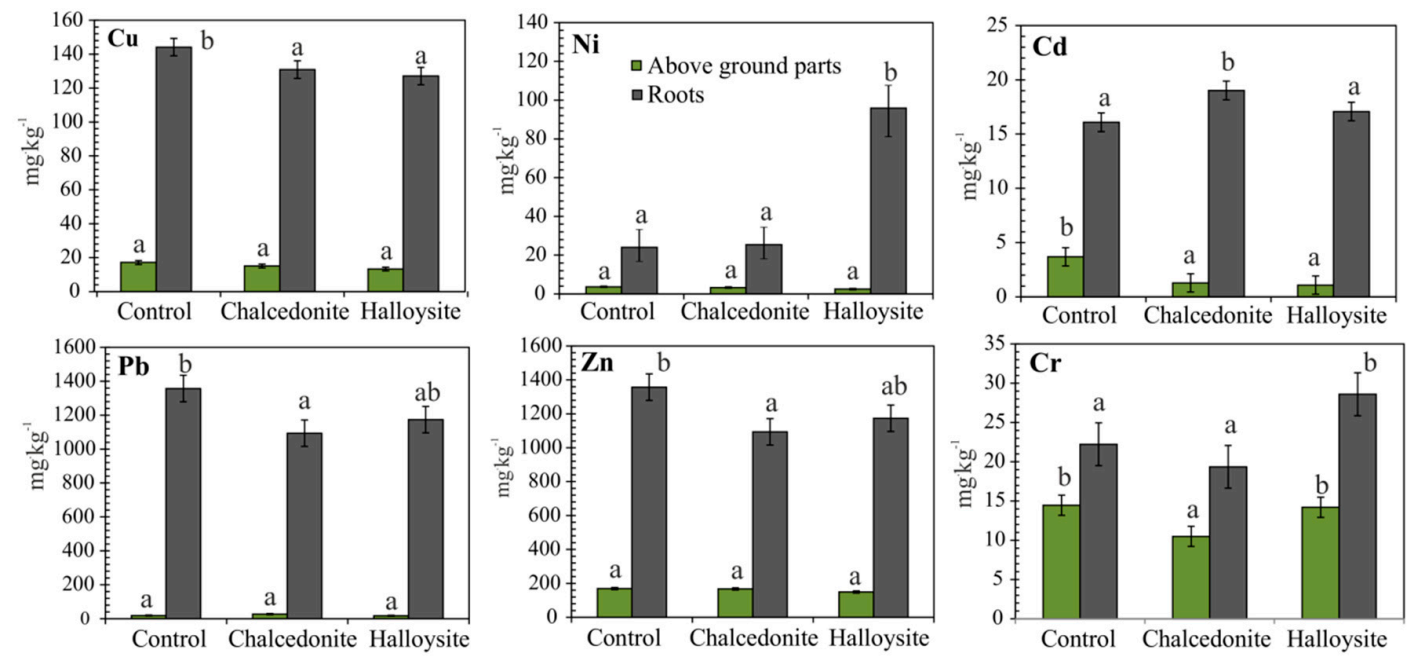

Figure 5. The effect of mineral-based amendments on potentially toxic elements accumulation in the roots and above-ground biomass of L. luteus. Error bars \pm standard error $(n=3)$. Different letters denote significant differences between treatments.

\subsection{Chlorophyll Fluorescence}

Chalcedonite and halloysite increased the value of $\mathrm{Fv} / \mathrm{Fm}$ in lupine leaves relative to the control treatment (Figure 6). The Fv/Fm ratio was determined at $0.73-0.74$ in control soil, $0.78-0.8$ in soil with the addition of halloysite, and $0.77-0.81$ in soil amended with chalcedonite.

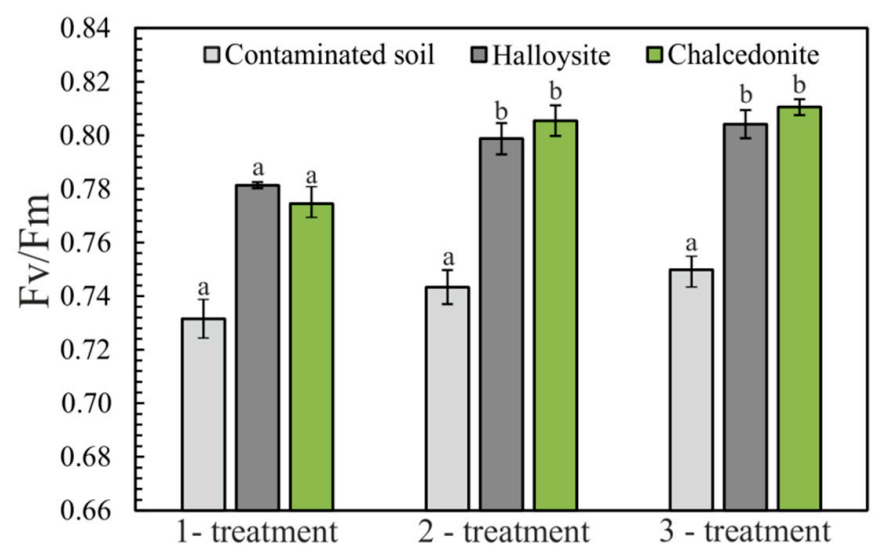

Figure 6. Leaf greenness index (SPAD). Different letters above the columns indicated significant difference at $p<0.05$.

\subsection{Leaf Greenness Index (SPAD)}

The leaf greenness index of lupine plants differed significantly across treatments containing the tested mineral-based amendments (Figure 7). In the first month of the experiment, the leaf greenness index was highest in soil containing chalcedonite (37.555 SPAD). The analyzed parameter was $22.0 \%$ lower on average (30.82 SPAD) in non-amended control soil. Similar trends were observed during the second and the third measurement. 


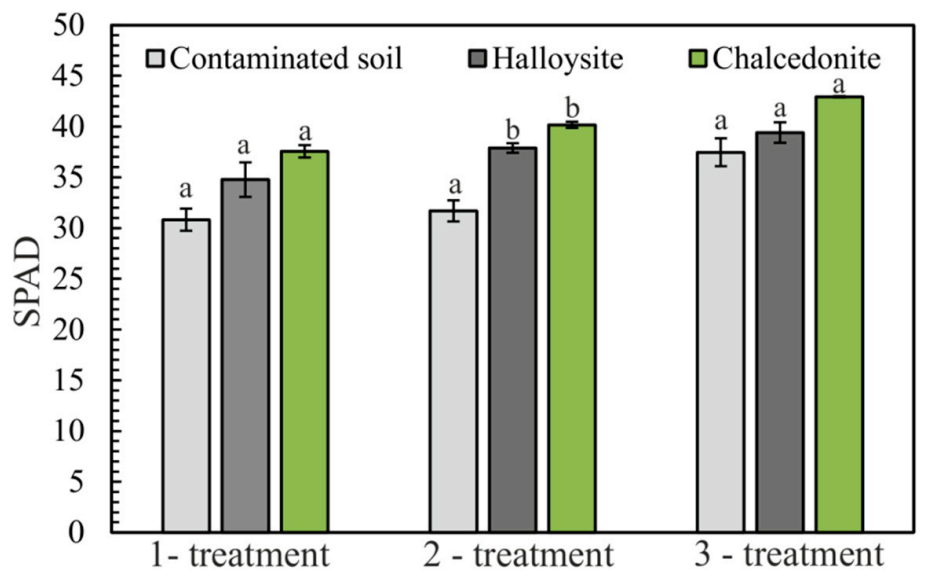

Figure 7. Chlorophyll $a$ fluorescence-the Fv/Fm ratio. Different letters above the columns indicated significant difference at the $p<0.05$.

\subsection{Phytotoxicity}

In phytotoxicity analyses of contaminated soil, the percentual inhibition of seed germination (GI) was generally lower $(16.6 \%$ on average for all samples) than the percentage inhibition of root growth (RI) $(41.9 \%$ on average for all samples) (Figure 8$)$. The tested mineral-based amendments had no significant effect on the germination of $S$. saccharatum seeds. Chalcedonite added to contaminated soil significantly differentiated the length of $S$. saccharatum roots relative to non-amended contaminated soil. The differences in root length observed in the tested plants growing in soil amended with halloysite were not statistically significant.

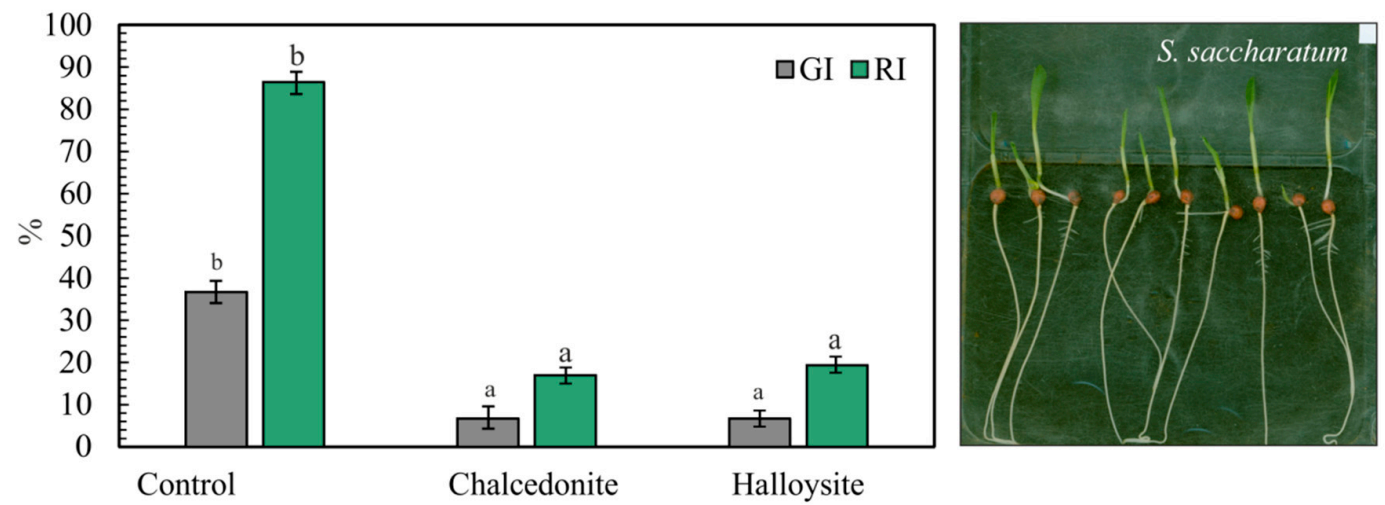

Figure 8. Growth inhibition (GI) and root growth (RI) of S. saccharatum before the phytostabilization experiment. Error bars represent standard deviation error (SD, $n=6$ determinations). Different letters denote significant differences between treatments.

\subsection{Statistical Analysis}

The suitability of the data for factor analysis was assessed using Kaiser-Meyer-Olkin (KMO) and Barlett Tests. The value of KMO $=0.518$ confirmed the suitability of the data for factor analysis. Two factors with eigenvalues greater than 1 were identified, where the ratio of the variance explained by each factor to the total variance decreased gradually (Table 3 and Figure 9). These two factors explained $100 \%$ of total variance. The first factor explained $58.73 \%$ of total variance. Biomass and the content of $\mathrm{Cd}, \mathrm{Ni}$, and $\mathrm{Cr}$ in the roots had strong negative loads; the content of $\mathrm{Cu}, \mathrm{Ni}$, and $\mathrm{Zn}$ in the above-ground parts of the tested plants, the content of $\mathrm{Cu}$ and $\mathrm{Ni}$ in the roots, and the content of $\mathrm{Ni}$ and $\mathrm{Zn}$ in the soil had strong positive loads, whereas the $\mathrm{Cd}$ content of the above-ground biomass and the $\mathrm{Cr}$ content of soil had moderately positive loads. The second factor explained $41.26 \%$ of total variance. $\mathrm{pH}$ and the $\mathrm{Pb}$ content of the above-ground parts had strong negative loads; the content of 
$\mathrm{Cu}$ and $\mathrm{Cd}$ in the soil, the content of $\mathrm{Pb}$ and $\mathrm{Zn}$ in the roots, and the $\mathrm{Cr}$ content of the above-ground parts had strong positive loads, whereas biomass had a moderately negative load.

Table 3. Varimax rotated factor matrix for the analyzed dataset.

\begin{tabular}{|c|c|c|}
\hline Variables & VF1 & VF2 \\
\hline Biomass & $-0.941 * * *$ & 0.339 \\
\hline $\mathrm{pH}$ & -0.010 & $-1.000 *$ \\
\hline $\mathrm{Cu}^{\mathrm{a}}$ & 0.604 & $0.797 * * *$ \\
\hline $\mathrm{Cu}^{\mathrm{b}}$ & $0.935^{* * *}$ & 0.355 \\
\hline $\mathrm{Cu}^{\mathrm{c}}$ & $0.808^{* * *}$ & 0.589 \\
\hline $\mathrm{Ni}^{\mathrm{a}}$ & $0.970 * * *$ & 0.241 \\
\hline $\mathrm{Ni}^{\mathrm{b}}$ & $0.995 * * *$ & 0.097 \\
\hline $\mathrm{Ni}^{\mathrm{c}}$ & $-0.983^{* * *}$ & 0.182 \\
\hline $\mathrm{Cd}^{\mathrm{a}}$ & 0.382 & $0.924 * * *$ \\
\hline $\mathrm{Cd}^{\mathrm{b}}$ & $0.711 * *$ & 0.703 \\
\hline $\mathrm{Cd}^{\mathrm{c}}$ & $-0.980 * * *$ & 0.198 \\
\hline $\mathrm{Pb}^{\mathrm{a}}$ & $0.934^{* * *}$ & 0.356 \\
\hline $\mathrm{Pb}^{\mathrm{b}}$ & 0.410 & $-0.912 * * *$ \\
\hline $\mathrm{Pb}^{\mathrm{C}}$ & -0.243 & $0.970 * * *$ \\
\hline $\mathrm{Zn}{ }^{\mathrm{a}}$ & $0.918 * * *$ & 0.396 \\
\hline $\mathrm{Zn}{ }^{b}$ & $0.995 * * *$ & -0.103 \\
\hline $\mathrm{Zn}^{\mathrm{c}}$ & 0.411 & $0.912 * * *$ \\
\hline $\mathrm{Cr}^{\mathrm{a}}$ & $0.723 * *$ & 0.690 \\
\hline $\mathrm{Cr}^{\mathrm{b}}$ & -0.263 & $0.965 * * *$ \\
\hline $\mathrm{Cr}^{\mathrm{c}}$ & $-0.874 * * *$ & 0.486 \\
\hline Eigenvalue & 12.634 & 7.366 \\
\hline Variability (\%) & 58.734 & 41.266 \\
\hline Cumulative \% & 58.734 & 100.000 \\
\hline
\end{tabular}

* Significant factor loading is bold faced $\left({ }^{* * *}\right.$ strong $>0.75$; ** medium $0.50-0.75 ;{ }^{*}$ weak $\left.0.50-0.30\right)$ [26] ${ }^{\text {a }}$ total content in soil; ${ }^{\mathrm{b}}$ metal contents in the above-ground plant material; ${ }^{\mathrm{c}}$ metal contents in the root.

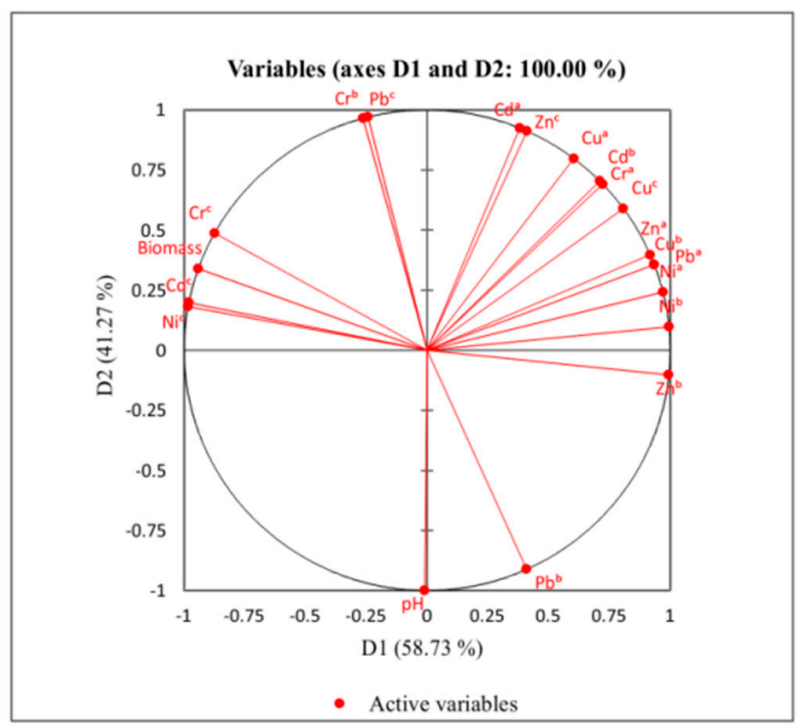

Figure 9. Plot of principal component scores (variables after varimax rotation).

The correlation matrix of PCA data is shown in Table 2. Significant negative correlations were found between biomass vs. the content of $\mathrm{Cu}$ in the above-ground parts of plants, $\mathrm{Cu}$ in the roots, $\mathrm{Ni}$ and $\mathrm{Pb}$ in the soil, $\mathrm{Pb}$ in the above-ground parts, $\mathrm{Zn}$ in the soil, and $\mathrm{Zn}$ in the above-ground parts ( $\mathrm{r}=-0.560$ to -0.971$)$, whereas significant positive correlations were noted between biomass vs. the content of $\mathrm{Ni}, \mathrm{Cd}, \mathrm{Pb}$, and $\mathrm{Cr}$ in the roots and $\mathrm{Cr}$ in the above-ground parts of L. luteus $(\mathrm{r}=-0.575$ 
to -0.989). Significant negative correlations were also observed between $\mathrm{pH}$ vs. the content of $\mathrm{Cu}$ and $\mathrm{Cd}$ in the soil, $\mathrm{Cu}$ in the roots, $\mathrm{Cd}$ in the above-ground parts, $\mathrm{Pb}$ and $\mathrm{Zn}$ in the roots, $\mathrm{Cr}$ in the soil, and $\mathrm{Cr}$ in the above-ground parts ( $\mathrm{r}=-0.597$ to -0.968$)$. The correlation analysis revealed that PTE parameters were strongly correlated with one another.

\section{Discussion}

In the present study, the total contents of $\mathrm{Cd}, \mathrm{Pb}$, and $\mathrm{Zn}$ considerably exceeded the threshold levels set forth by the Regulation of the Polish Ministry of the Environment [25]. The effectiveness of phytoremediation in degraded areas can be improved through the addition of amendments that decrease erosion and/or the transfer of PTE to deep soil horizons and reduce the quantity of phytoavailable metals in soil [27]. The applied amendments immobilize PTE in soil, thus contributing to the reinstatement of the physiochemical and functional properties of degraded soils. In the current study, halloysite enhanced the immobilization of metals ( $\mathrm{Ni}, \mathrm{Pb}, \mathrm{Zn}$, and $\mathrm{Cr}$ ) in soil, which could be attributed to its large specific surface area and cation exchange capacity [22]. Halloysite's ability to immobilize PTE in contaminated soil was also reported in our previous studies which demonstrated that this mineral-based amendment effectively immobilized $\mathrm{Ni}$ [28], $\mathrm{Pb}, \mathrm{Zn}$ [29], and $\mathrm{Cu}$ [30]. PTE-binding affinity is influenced by the granulometric composition, organic matter content, and $\mathrm{pH}$ of soil [31]. The mobility of PTEs decreases with an increase in soil $\mathrm{pH}$. Potential toxic elements are less bioavailable in alkaline soils. According to Blake and Goulding [32], the bioavailability of $\mathrm{Cd}$ increases at $\mathrm{pH}>5.5$, the bioavailability of $\mathrm{Zn}, \mathrm{Ni}$, and $\mathrm{Cu}$ increases at $\mathrm{pH} 5.0$, and the bioavailability of $\mathrm{Pb}$ at $\mathrm{pH}<4.5$. In the present study, the greatest increase in soil $\mathrm{pH}$ was observed in the treatment containing chalcedonite. A significant increase in soil $\mathrm{pH}$ was also reported by Jin et al. [33] and Abad-Valle et al. [34] who analyzed the effectiveness of mineral-based amendments (nano-hydroxyapatite, sepioloite) in the remediation of PTE-polluted soils, which is consistent with the present findings. Mineral-based amendments can promote assisted phytostabilization by inducing the immobilization of pollutants in soil [29].

In the present study, halloysite and chalcedonite considerably decreased the total PTE content of soil by increasing soil $\mathrm{pH}$ and, consequently, reducing the mobility and bioavailability of PTE. High contents of PTE have toxic effects on plants, and they compromise or inhibit plant growth and development [35]. Heavily contaminated soils can be sown with plant species that are highly tolerant of pollution [36]. In the current study, soils contaminated with high levels of PTE were effectively remediated through the combined application of L. luteus and mineral-based amendments. In other studies, mineral-based amendments such as zeolite, $\mathrm{CaO}$, bentonite, and dolomite effectively immobilized PTE in soil and increased the yields of the tested plants [37]. The mechanism by which plant roots absorb PTE is highly complex and involves several processes, including cation exchange across cell walls, intracellular transport and rhizosphere processes [38,39]. Plant cover can limit the migration of PTE to deeper soil horizons and above-ground plant parts by stabilizing pollutants in the rhizosphere [40]. The results of this study validate the above observation. According to the literature, PTE absorbed from the soil solution are more likely to be accumulated in roots than in shoots, proportionally to their content in the soil [41,42]. The analyzed PTE were accumulated mainly in lupine roots, in particular in soil amended with halloysite. In the extensive root system, the mineralization of old roots also increases the organic matter content of soil and promotes the immobilization of contaminating PTE [43]. Other studies have demonstrated that plants used for phytostabilization effectively absorb PTE, and the absorption of $\mathrm{Zn}, \mathrm{Pb}, \mathrm{Cd}$, and $\mathrm{Ni}$ by plant roots generally increases with a rise in pollution levels $[29,30]$. The applied plants should be characterized by low fertilizer, water, and pesticide requirements, high efficiency of the photosynthetic apparatus, and they should be well adapted to the local climate [44]. Previous research [45,46] and the present findings indicate that PTE impair chlorophyll synthesis and decrease the chlorophyll content of plants. Plant resistance to toxic levels of PTE varies across species and varieties. Despite the fact that PTE are bound by various organic substances (proteins and amino acids), these pollutants decrease the chlorophyll content of plants, thus 
reducing photosynthetic efficiency [47]. The roots are the first plant organs to come into contact with and respond to PTE in soil, which was also observed in S. saccharatum in this study. The percentual inhibition of seed germination and root growth indicates that the analyzed soil was characterized by low toxicity for the tested plant species.

\section{Conclusions}

Degraded post-industrial areas are characterized by adverse physicochemical properties, including high contents of PTE, which inhibit the development of vegetation. In the present study, the addition of halloysite to contaminated soil significantly increased L. luteus biomass. The above mineral-based amendment was also most effective in reducing the total contents of $\mathrm{Ni}, \mathrm{Pb}, \mathrm{Zn}$, and $\mathrm{Cr}$ in soil. Chalcedonite led to the highest increase in soil $\mathrm{pH}$ relative to the control treatment. The uptake of PTE by L. luteus plants depended on the type of metal and the applied mineral-based amendments. The total content of PTE was higher in the roots than in the above-ground parts of L. luteus plants. The Ni and $\mathrm{Cr}$ content in roots was significantly higher in soil amended with halloysite than in the control treatment. The application of mineral-based amendments increased the Fv/Fm ratio in yellow lupine leaves. The leaf greenness index was highest in plants growing in soil amended with chalcedonite. Chalcedonite significantly differentiated the length of $S$. saccharatum roots.

Author Contributions: Author Contributions: Conceptualization, M.R. and Z.M.G.; methodology, M.R.; software, A.B. (Agnieszka Bęś), G.M., A.B. (Ayla Bilgin); validation, Z.M., G.M. and Z.M.; formal analysis, G.M.; investigation, M.R.; resources, Z.M.; data curation, I.J.; writing—original draft preparation, M.R.; writing—review and editing, Z.M.G.; visualization, M.B.; supervision, M.R. and Z.M.G. All authors have read and agreed to the published version of the manuscript.

Funding: This research was funded by a project financially supported by the Ministry of Science and Higher Education in the auspices of the program entitled "Regional Initiative of Excellence" for the years 2019-2022, Project No. 010/RID/2018/19 (amount of funding 12,000,000 PLN).

Conflicts of Interest: The authors declare no conflicts of interest.

\section{References}

1. Christophoridis, C.; Bourliva, A.; Evgenakis, E.; Papadopoulou, L.; Fytianos, K. Effects of anthropogenic activities on the levels of heavy metals in marine surface sediments of the Thessaloniki Bay, Northern Greece: Spatial distribution, sources and contamination assessment. Microchem. J. 2019, 149, 104001. [CrossRef]

2. Caridi, F.; Pappaterra, D.; Belmusto, G.; Messina, M.; Belvedere, A.; D'Agostino, M.; Settineri, L. Radioactivity and heavy metals concentration in Italian (Calabrian) DOC Wines. Appl. Sci. 2019, 9, 4584. [CrossRef]

3. Tang, J.; Zhang, J.; Ren, L.; Zhou, Y.; Gao, J.; Luo, L.; Yang, Y.; Peng, Q.; Huang, H.; Chen, A. Diagnosis of soil contamination using microbiological indices: A review on heavy metal pollution. J. Environ. Manag. 2019, 242, 121-130. [CrossRef] [PubMed]

4. Sas, W.; Dzięcioł, J.; Głuchowski, A. Estimation of recycled concrete aggregate's water permeability coefficient as earth construction material with the application of an analytical method. Materials 2019, 12, 2920. [CrossRef]

5. Odoh, C.K.; Zabbey, N.; Sam, K.; Eze, C.N. Status, progress and challenges of phytoremediation-An African scenario. J. Environ. Manag. 2019, 237, 365-378. [CrossRef] [PubMed]

6. Li, Y.; Chiou, C.T.; Li, H.; Schnoor, J.L. Improved prediction of the bioconcentration factors of organic contaminants from soils into plant/crop roots by related physicochemical parameters. Environ. Int. 2019, 126, 46-53. [CrossRef] [PubMed]

7. Luo, Y.; Wu, Y.; Shu, J.; Wu, Z. Effect of particulate organic matter fractions on the distribution of heavy metals with aided phytostabilization at a zinc smelting waste slag site. Environ. Pollut. 2019, 253, 330-341. [CrossRef] [PubMed]

8. Castaldi, P.; Silvetti, M.; Manzano, R.; Brundu, G.; Roggero, P.P.; Garau, G. Mutual effect of Phragmites australis, Arundo donax and immobilization agents on arsenic and trace metals phytostabilization in polluted soils. Geoderma 2018, 314, 63-72. [CrossRef] 
9. Tauqeer, H.M.; Rahman, M.; Hussain, S.; Abbas, F.; Iqbal, M. The potential of an energy crop “Conocarpus erectus" for lead phytoextraction and phytostabilization of chromium, nickel, and cadmium: An excellent option for the management of multi-metal contaminated soils. Ecotoxicol. Environ. Saf. 2019, 173, 273-284. [CrossRef]

10. Mahmoud, E.; Abd El-Kader, N. Heavy metal immobilization in contaminated soils using phosphogypsum and rice straw compost. Land Degrad. Dev. 2015, 26, 819-824. [CrossRef]

11. Houben, D.; Pircar, J.; Sonnet, P. Heavy metal immobilization by cost-effective amendments in a contaminated soil: Effects on metal leaching and phytoavailability. J. Geochem. Explor. 2012, 123, 87-94. [CrossRef]

12. Labidi, A.; Firmin, S.; Verdin, A.; Bidar, G.; Laruelle, F.; Douay, F.; Shirali, P.; Fontaine, J.; Sahraoui, A.L.H. Nature of fly ash amendments differently influences oxidative stress alleviation in four forest tree species and metal trace element phytostabilization in aged contaminated soil: A long-term field experiment. Ecotoxicol. Environ. Saf. 2017, 138, 190-198. [CrossRef] [PubMed]

13. Waterlot, C.; Pruvot, C.; Marot, F.; Douay, F. Impact of a phosphate amendment on the environmental availability and phytoavailability of $\mathrm{Cd}$ and $\mathrm{Pb}$ in moderately and highly carbonated kitchen garden soils. Pedosphere 2017, 27, 588-605. [CrossRef]

14. Parra, A.; Zornoza, R.; Conesa, E.; Gómez-López, M.D.; Faz, A. Seedling emergence, growth and trace elements tolerance and accumulation by Lamiaceae species in a mine soil. Chemosphere 2014, 113, 132-140. [CrossRef]

15. Pardo, T.; Clemente, R.; Epelde, L.; Garbisu, C.; Bernal, M.P. Evaluation of the phytostabilisation efficiency in a trace elements contaminated soil using soil health indicators. J. Hazard. Mater. 2014, 268, 68-76. [CrossRef]

16. Radziemska, M.; Gusiatin, Z.M.; Bilgin, A. Potential of using immobilizing agents in aided phytostabilization on simulated contamination of soil with lead. Ecol. Eng. 2017, 102, 490-500. [CrossRef]

17. Fronczyk, J. Artificial road runoff water treatment by a pilot-scale horizontal permeable treatment zone. Ecol. Eng. 2017, 107, 198-207. [CrossRef]

18. Fronczyk, J.; Radziemska, M.; Jeznach, J. Evaluation of diatomite and chalcedonite as reactive materials protecting groundwater in traffic infrastructure. Fres. Environ. Bull. 2014, 23, 3331-3339.

19. Hermawan, A.A.; Chang, J.W.; Pasbakhsh, P.; Hart, F.; Talei, A. Halloysite nanotubes as a fine grained material for heavy metal ions removal in tropical biofiltration systems. Appl. Clay Sci. 2018, 160, 106-115. [CrossRef]

20. Meng, Q.; Chen, H.; Lin, J.; Lin, Z.; Sun, J. Zeolite A synthesized from alkaline assisted pre-activated halloysite for efficient heavy metal removal in polluted river water and industrial wastewater. J. Environ. Sci. 2017, 56, 254-262. [CrossRef]

21. Anastopoulos, I.; Mittal, A.; Usman, M.; Mittal, J.; Yu, G.; Núñez-Delgado, A.; Kornaros, M.A. review on halloysite-based adsorbents to remove pollutants in water and wastewater. J. Mol. Liq. 2018, 269, 855-868. [CrossRef]

22. Lutyński, M.; Sakiewicz, P.; Lutyńska, S. Characterization of diatomaceous earth and halloysite resources of Poland. Minerals 2019, 9, 670. [CrossRef]

23. Banaś, D.; Kubala-Kukuś, A.; Braziewicz, J.; Majewska, U.; Pajek, M.; Wudarczyk-Moćko, J.; Czech, K.; Garnuszek, M.; Słomkiewicz, P.; Szczepanik, B. Study of properties of chemically modified samples of halloysite mineral with X-ray fluorescence and X-ray powder diffraction methods. Radiat. Phys. Chem. 2013, 93, 129-134. [CrossRef]

24. Pan, L.B.; Wang, S.Y.; Ma, J.; Fang, D. Gridded field observations of polycyclic aromatic hydrocarbons in soils from a typical county in Shanxi Province, China. Arch. Environ. Contam. Tox. 2015, 68, 323-329. [CrossRef]

25. Regulation of the Minister of the Environment on September 2016 on the Standards of the Soil Quality and Ground Quality 1.09.2016, No 165, 1359; Polish Ministry of Environmental Protection: Warsaw, Poland, 2016. (In Polish)

26. Liu, C.W.; Lin, K.H.; Kuo, Y.M. Application of factor analysis in the assessment of groundwater quality in a black foot disease area in Taiwan. Sci. Total Environ. 2003, 313, 77-89. [CrossRef]

27. Lebrun, V.E.M.; Miard, F.; Nandillon, R.; Léger, J.C.; Hattab-Hambli, N.; Scippa, G.S.; Bourgerie, S.; Morabito, D. Assisted phytostabilization of a multi contaminated mine technosol using biochar amendment: Early stage evaluation of biochar feedstock and particle size effects on $\mathrm{As}$ and $\mathrm{Pb}$ accumulation of two Salicaceae species (Salix viminalis and Populus euramericana). Chemosphere 2018, 194, 316-326. [CrossRef]

28. Radziemska, M.; Mazur, Z.; Fronczyk, J.; Matusik, J. Co-remediation of Ni-contaminated soil by halloysite and Indian mustard (Brassica juncea L.). Clay Min. 2016, 51, 489-497. [CrossRef] 
29. Radziemska, M. Study of applying naturally occurring mineral sorbents of Poland (dolomite, halloysite, chalcedonite) for aided phytostabilization of soil polluted with heavy metals. Catena 2018, 163, 123-129. [CrossRef]

30. Radziemska, M.; Vaverková, M.D.; Baryła, A. Phytostabilization-Management strategy for stabilizing trace elements in contaminated soils. Int. J. Environ. Res. Public Health. 2017, 14, 958. [CrossRef]

31. Hou, S.; Zheng, N.; Tang, L.; Ji, X.; Li, Y. Effect of soil $\mathrm{pH}$ and organic matter content on heavy metals availability in maize (Zea mays L.) rhizospheric soil of non-ferrous metals smelting area. Environ. Monit. Asses. 2019, 191, 634. [CrossRef]

32. Blake, L.; Goulding, K.W.T. Effects of atmospheric deposition, soil $\mathrm{pH}$ and acidification on heavy metal contents in soils and vegetation of semi-natural ecosystems at Rothamsted Experimental Station, UK. Plant Soil 2002, 240, 235-251. [CrossRef]

33. Jin, Y.; Liu, W.; Li, H.-L.; Shen, S.-G.; Liang, S.-X.; Liu, C.; Shan, L. Nano-hydroxyapatite immobilized lead and enhanced plant growth of ryegrass in a contaminated soil. Ecol. Eng. 2016, 95, 25-29. [CrossRef]

34. Abad-Valle, P.; Álvarez-Ayuso, E.; Murciego, A.; Pellitero, E. Assessment of the use of sepiolite amendment to restore heavy metal polluted mine soil. Geoderma 2016, 280, 57-66. [CrossRef]

35. Vardhan, K.H.; Kumar, P.S.; Panda, R.C. A review on heavy metal pollution, toxicity and remedial measures: Current trends and future perspectives. J. Mol. Liq. 2019, 290, 111197. [CrossRef]

36. Ghazaryan, K.; Movsesyan, H.; Ghazaryan, N.; Watts, B.A. Copper phytoremediation potential of wild plant species growing in the mine polluted areas of Armenia. Environ. Pollut. 2019, 249, 491-501. [CrossRef]

37. Radziemska, M.; Wyszkowski, M.; Bęś, A.; Mazur, Z.; Jeznach, J.; Brtnický, M. The applicability of compost, zeolite and calcium oxide in assisted remediation of acidic soil contaminated with Cr (III) and Cr (VI). Environ. Sci. Pollut. Res. 2019, 26, 21351-21362. [CrossRef]

38. Rai, P.K.; Lee, S.S.; Zhang, M.; Tsang, Y.F.; Kim, K.H. Heavy metals in food crops: Health risks, fate, mechanisms, and management. Environ. Int. 2019, 125, 365-385. [CrossRef]

39. Taghipour, M.; Jalali, M. Impact of some industrial solid wastes on the growth and heavy metal uptake of cucumber (Cucumis sativus L.) under salinity stress. Ecotoxicol. Environ. Saf. 2019, 182, 109347. [CrossRef]

40. Kim, K.R.; Owens, G.; Kwon, S.I. Influence of Indian mustard (Brassica juncea) on rhizosphere soil solution chemistry in long-term contaminated soils: A rhizobox study. J. Environ. Sci. 2010, 22, 98-105. [CrossRef]

41. Tian, S.; Liang, S.; Qiao, K.; Wang, F.; Zhang, Y.; Chai, T. Co-expression of multiple heavy metal transporters changes the translocation, accumulation, and potential oxidative stress of $\mathrm{Cd}$ and $\mathrm{Zn}$ in rice (Oryza sativa). J. Hazard. Mat. 2019, 380, 120853. [CrossRef]

42. Lebrun, M.; De Zio, E.; Miard, F.; Scippa, G.S.; Renzone, G.; Scaloni, A.; Bourgerie, S.; Morabito, D.; Trupiano, D. Amending an $\mathrm{As} / \mathrm{Pb}$ contaminated soil with biochar, compost and iron grit: Effect on Salix viminalis growth, root proteome profiles and metal(loid) accumulation indexes. Chemosphere 2020, 244, 125397. [CrossRef] [PubMed]

43. Ying, M.; Yasuda, H.; Kobayashi, S.; Sakurai, N.; Kidou, S.I. Barley cold-induced CISP proteins contribute to the accumulation of heavy metals in roots. Environ. Exp. Bot. 2019, 165, 53-58. [CrossRef]

44. Dabrowski, P.; Baczewska-Dabrowska, A.H.; Kalaji, H.M.; Goltsev, V.; Paunov, M.; Rapacz, M.; Wojcik-Jagla, M.; Pawluskiewicz, B.; Baba, W.; Brestic, M. Exploration of chlorophyll a fluorescence and plant gas exchange parameters as indicators of drought Tolerance in Perennial Ryegrass. Sensors 2019, 19, 2736. [CrossRef] [PubMed]

45. Dabrowski, P.; Pawluskiewicz, B.; Kalaji, H.M.; Baczewska, A.H. The effect of light availability on leaf area index, biomass production and plant species composition of park grasslands in Warsaw. Plant Soil Environ. 2013, 59, 543-548. [CrossRef]

46. Bes, A.; Warminski, K.; Adomas, B. Long-term responses of Scots pine (Pinus sylvestris L.) and European beech (Fagus sylvatica L.) to the contamination of light soils with diesel oil. Environ. Sci. Pollut. Res. 2019, 26, 10587-10608. [CrossRef]

47. Hashemi, S.A. Studying the effects of heavy metal on chlorophyll and sugar in one year-old seedlings organs of Acer velutinum specie. Acta Ecol. Sin. 2018, 38, 224-227. [CrossRef]

(C) 2020 by the authors. Licensee MDPI, Basel, Switzerland. This article is an open access article distributed under the terms and conditions of the Creative Commons Attribution (CC BY) license (http://creativecommons.org/licenses/by/4.0/). 